\title{
Prevalence of hepatitis $C$ virus infection and associated factors among male illicit drug users in Cuiabá, Mato Grosso, Brazil
}

\author{
Antônia Carlos Magalhães Novais ${ }^{1}$, Carmen Luci Rodrigues Lopes², Nádia Rúbia da Silva Reis², \\ Ágabo Macêdo Costa e Silva ${ }^{3}$, Regina Maria Bringel Martinss ${ }^{3}$, Francisco José Dutra Souto $/^{+}$
}

${ }^{1}$ Faculdade de Medicina, Universidade de Cuiabá, Cuiabá, MT, Brasil ${ }^{2}$ Faculdade de Enfermagem ${ }^{3}$ Departamento de Virologia, Instituto de Patologia Tropical e Saúde Pública, Universidade Federal de Goiás, Goiânia, GO, Brasil ${ }^{4}$ Departamento de Clínica Médica, Faculdade de Ciências Médicas, Hospital Universitário Júlio Müller, Universidade Federal de Mato Grosso, Rua Luis Philipe Pereira Leite s/n, 78048-902 Cuiabá, MT, Brasil

Intravenous drug injection has been reported as the main risk factor for hepatitis C virus (HCV) infection. The aim of the present study was to describe the prevalence and the epidemiological profile of HCV infection among abusers of illegal injected and non-injected drugs in Cuiabá, state of Mato Grosso, Central Brazil. A cross-sectional study including 314 male drug users from eight detoxification centres was performed. Out of 314 subjects studied, $48(15.2 \%)$ were intravenous drug users. Participants were interviewed and had blood samples taken and tested for the presence of anti-HCV antibodies. Positive samples were tested for the presence of HCV RNA. Genotyping was performed on HCV RNA-positive samples. The overall prevalence of anti-HCV antibodies was $6.4 \%(n=20)$. Out of 20 anti-HCV antibody-positive subjects, 16 (80\%) were also HCV RNA-positive. Genotype 1 predominated (75\%), followed by 3 a (25\%). Subtype la was more common than $1 b$. HCV infection was more prevalent among intravenous drug users (33\%) than non-injecting users (1.5\%). Logistic regression analyses showed independent associations between HCV infection and intravenous drug use, imprisonment and increasing age. In the present study, injecting drug use was the factor most strongly associated to HCV infection and inhaling or sniffing did not represent an increased susceptibility to infection.

Key words: epidemiology - hepatitis C virus - illicit drug users - HCV prevalence - HCV epidemiology

Hepatitis $\mathrm{C}$ virus $(\mathrm{HCV})$ is a common cause of liver disease and a major public health issue worldwide (Kew et al. 2004, Scheinmann et al. 2007). HCV is transmitted efficiently via the parenteral route, whereas transmission is less common due to sexual or perinatal contact. Estimates indicate that there are $\sim 170$ million people infected worldwide. In the West, the HCV-positive population ranges from less than 1-2\% (Shepard et al. 2005).

$\mathrm{HCV}$ is characterised by a high genetic variability and is classified into six major genotypes. Genotype 1 is the most prevalent worldwide, followed by genotypes 3 and 2 (Sablon \& Shapiro 2004). In most Brazilian regions, genotype 1 is the etiologic agent in $60-75 \%$ of $\mathrm{HCV}$ infections (Paraná et al. 2000, Campiotto et al. 2005, Martins et al. 2006). Genotype 3 is the second-most prevalent strain and genotype 2 constitutes less than 5\% of cases.

Intravenous drug users are considered to be the main risk group for $\mathrm{HCV}$ infection and act as a reservoir for this blood-borne virus. Prevalence of anti-HCV antibodies among intravenous drug users ranges from $31-98 \%$ around the world and increases proportionally according to the duration of intravenous drug use (Memon \&

\footnotetext{
Financial support: CNPq, SCTIE-DECIT (MS)

+Corresponding author: fsouto@ufmt.br

Received 29 April 2009

Accepted 12 August 2009
}

Memon 2002). Generally, genotypes 3a and la have been found more frequently in this group (Stark et al. 1995, Lanternier et al. 2007).

The aim of this study was to estimate the prevalence of $\mathrm{HCV}$ infection and the main genotypes circulating among illicit drug users in the capital of the state of Mato Grosso (MT), Cuiabá, Central Brazil. We also tried to identify factors associated with $\mathrm{HCV}$ infection in this population.

\section{PATIENTS, MATERIALS AND METHODS}

A cross-sectional study was designed in order to assess illicit drug users (injecting and non-injecting) who are or have been receiving treatment either during day visits or while staying in rehabilitation centres in the city of Cuiabá in 2007.

The eight main centres offering this service were included. A peculiarity of all of these centres is that they only treat male patients. Thus, female patients were not included. Four other centres that had a small number of individuals in treatment were not visited due to access and logistical difficulties.

The volunteers were approached in their respective treatment centres. Those who agreed to participate were interviewed in an isolated room after written informed consent was obtained. All of the interviews were conducted by a single interviewer. The patients were asked questions regarding socio-demographics and the characteristics of their drug use, such as the type of $\operatorname{drug}(\mathrm{s})$ consumed, consumption method, amount of time taken to consume the drug(s) and the frequency of consumption, sharing of needles, syringes 
and other instruments and risk factors associated with infection from blood-borne agents, such as surgery, acupuncture, number of sexual partners and history of sexually transmitted diseases (STD).

After the interviews, $10 \mathrm{~mL}$ of blood were collected from one of the cubital veins. The samples were wrapped, frozen and taken to the Laboratory of Virology at the Institute of Tropical Pathology and Public Health at the Federal University of Goiás, in Goiânia, state of Goiás, Central Brazil.

The samples were tested for the presence of anti$\mathrm{HCV}$ antibodies using a third generation enzyme immunoassay (ELISA) (Abbott Laboratories, Abbott Park, IL, USA). Positive samples were retested for confirmation using a line immunoassay (INNO-LIA HCV Ab III, Innogenetics). All samples were subjected to RNA extraction, reverse transcription and a nested PCR with primers complementary to the conserved area of the $5^{\prime} \mathrm{NC}$ region of $\mathrm{HCV}$, essentially as described by Ginabreda et al. (1997). HCV genotyping was carried out for all HCV-RNA-positive samples. A line probe assay (InnoLiPA HCV II, Innogenetics) was used to determine the genotype of the amplicons of the 5' NC region according to the procedure described by the manufacturer.

Current or previous hepatitis B Virus (HBV) infection markers (HBsAg, anti-HBc and anti-HBs) were assessed by ELISA (Hepanostika Uni-form Organon Teknica BV, Boxtel, Holland). Human immunodeficiency virus (HIV)-1 and HIV-2 antibodies were also measured by ELISA (Wiener Laboratories SAIC, Rosário, Argentina). Positive samples were submitted for confirmatory testing by western blot assay (Bio-Rad Laboratories, California, USA).

The data obtained were stored using the software Epi Info $6.04 \mathrm{~d}$ (Centres for Disease Control and Prevention, Atlanta, USA). Statistical tests for univariate analyses were performed to compare continuous and categorical variables, with respective dispersion and a confidence interval of $95 \%$ (CI 95\%), using the same tool. All patients who were positive for anti-HCV antibodies by ELISA were considered to have been exposed to HCV. Another univariate analysis was performed using the results of PCR assays designed to detect HCV RNA as the dependent variable.

All variables with $p<0.20$ in univariate analyses were entered into multivariate logistic regression models using a stepwise method in order to analyse the association with the presence of anti-HCV antibodies or HCV RNA. For this analysis, the software Stata 8.2 (Stata Corporation, College Station, Texas, USA, 2005) was used.

The protocol for this study was approved by the Committee of Ethical for Research on Human Beings of the Public Health School of MT (protocol 132/06 - CEP/SESMT) on May 9th 2006. All centres' directors gave approval for the study and the structured interview instrument.

\section{RESULTS}

Three-hundred and forty-one drug users who were receiving treatment at one of the eight rehabilitation centres were approached between June 2006-January 2007. It was not possible to collect blood from 27 (7.9\%) of these individuals due to initial refusal, technical difficulties or failure to report for testing. Thus data from 314 individuals were included in the analyses. The participants and missing subjects did not differ in age or other demographic characteristics.

\section{TABLE I}

Demographic characteristics and risk factors for users of illicit drugs who received treatment in rehabilitation centers in Cuiabá, Mato Grosso, Brazil

\begin{tabular}{|c|c|c|c|}
\hline Characteristics & $\mathrm{n}$ & $\%$ & IC $95 \%$ \\
\hline \multicolumn{4}{|l|}{ Ethnic group } \\
\hline White & 172 & 54.8 & $49.1-60.4$ \\
\hline Non-white & 142 & 45.2 & $39.4-50.7$ \\
\hline \multicolumn{4}{|l|}{ Education level } \\
\hline Primary & 172 & 54.8 & $49.1-60.4$ \\
\hline Secondary & 111 & 35.4 & $30.1-40.9$ \\
\hline Tertiary & 26 & 8.3 & $5.6-12.0$ \\
\hline \multicolumn{4}{|l|}{ Age (years) } \\
\hline$<20$ & 24 & 7.6 & $5.1-11.3$ \\
\hline $20-30$ & 185 & 58.9 & $53.3-64.4$ \\
\hline $30-40$ & 23 & 26.4 & $21.7-31.7$ \\
\hline$\geq 40$ & 22 & 7.0 & $4.5-10.6$ \\
\hline \multicolumn{4}{|l|}{ Blood transfusion } \\
\hline No & 261 & 83.1 & $78.5-87.1$ \\
\hline Yes & 39 & 12.4 & $9.1-16.7$ \\
\hline \multicolumn{4}{|l|}{ Surgery } \\
\hline No & 203 & 64.6 & $59.1-69.9$ \\
\hline Yes & 111 & 35.4 & $30.1-40.9$ \\
\hline \multicolumn{4}{|l|}{ Tattoo } \\
\hline No & 152 & 48.4 & $42.8-54.1$ \\
\hline Yes & 162 & 51.6 & $45.9-57.2$ \\
\hline \multicolumn{4}{|l|}{ Number of partners ${ }^{a}$} \\
\hline $1-10$ & 52 & 16.7 & $12.8-21.4$ \\
\hline $10-30$ & 101 & 32.4 & $27.3-37.9$ \\
\hline $30-50$ & 51 & 16.3 & $12.5-21.0$ \\
\hline$\geq 50$ & 108 & 34.6 & $29.4-40.2$ \\
\hline \multicolumn{4}{|l|}{ Homosexual relations } \\
\hline No & 197 & 62.9 & $57.3-68.3$ \\
\hline Yes & 116 & 37.1 & $31.7-42.7$ \\
\hline \multicolumn{4}{|l|}{ Sexually transmitted diseases } \\
\hline No & 202 & 64.3 & $58.8-69.6$ \\
\hline Yes & 111 & 35.4 & $30.1-40.9$ \\
\hline \multicolumn{4}{|l|}{ Imprisonment } \\
\hline No & 92 & 29.3 & 24.4-34.7 \\
\hline Yes & 222 & 70.7 & $65.3-75.7$ \\
\hline \multicolumn{4}{|l|}{ Tobacco use } \\
\hline No & 36 & 11.5 & $8.3-15.6$ \\
\hline Yes & 278 & 88.5 & $84.5-91.8$ \\
\hline \multicolumn{4}{|l|}{ Alcohol use } \\
\hline No & 51 & 16.2 & $12.4-20.9$ \\
\hline Yes & 263 & 83.8 & $79.2-87.7$ \\
\hline \multicolumn{4}{|l|}{ Drug use route } \\
\hline Only non-injecting & 266 & 84.7 & $80.2-88.5$ \\
\hline Injecting and non-injecting & 48 & 15.3 & 11.6-19.8 \\
\hline
\end{tabular}

$a$ : one patient had not had sexual relations and another did not know the number of partners. 


\section{TABLE II}

Multiple regression analysis models for the factors associated with the presence of anti hepatitis $\mathrm{C}$ virus antibodies by ELISA among users of illicit drugs attended in rehabilitation centres in Cuiabá, Mato Grosso, Brazil

\begin{tabular}{lrrrc}
\hline Variable & $\mathrm{OR}_{\text {crude }}$ & $\mathrm{OR}_{\text {adjusted }}$ & $\mathrm{CI} 95 \%$ & $\mathrm{p}$ \\
\hline Drug use route & & & & \\
Non-injecting drug users & 1.0 & 1.0 & - & \\
Injecting drug users & 33.8 & 22.5 & $6.6-76.3$ & $<0.001$ \\
Age (years) & 1.1 & 1.1 & $1.1-1.2$ & $<0.01$ \\
Imprisonment & & & & \\
No & 1.0 & 1.0 & - & \\
Yes & 4.0 & 5.8 & $1.1-30.8$ & 0.04 \\
\hline
\end{tabular}

individuals included in the model: 314 . Model's p-value $<0.001$.

The average participant age was $27.9 \pm 7.7$ years, with a median age of 27 years. The main age range was $20-30$ years $(58.9 \% ; \mathrm{n}=185)$. Of the 314 participants, 39 (12.4\%) had undergone blood transfusions, 203 (64.6\%) had had surgery and $67(51.6 \%)$ had tattoos. The vast majority $(70.7 \%)$ had served time in prison.

Only one participant had not had sexual contact. Of the 314 participants, 101 (32.4\%) had between 10-30 sexual partners and 108 (34.6\%) had more than 50. STD histories were present for 111 (35.4\%) participants; these data are shown in Table I.

Most of the participants ( $85.9 \%$ ) became addicted to drugs between the ages of 10-20 years and now declared daily use (83.4\%). Two-hundred and sixty-six $(84.7 \%)$ of the interviewees used non-injected drugs only, the most common of which were marijuana $(94.9 \%)$, cocaine $(92 \%)$, cocaine basic paste $(89 \%)$, solvents $(67 \%)$ and crack $(33 \%)$. The other $48(15.3 \%)$ had used or were still using intravenous drugs, the most prevalent being cocaine (77.1\%). Tobacco smoking (88.5\%) and the consumption of alcoholic beverages (83.8\%) were common habits.

There were 20 anti-HCV antibody-reactive participants (6.4\%; CI 95\%: 4.0-9.8\%). HCV RNAs were detected in 16 of the interviewees (5.1\%; CI 95\%: 3.0-8.3\%). Overall, genotype 1 was identified in 12 (75\%) out of 16 $\mathrm{HCV}$-positive participants. Genotyping showed that subtype 1a predominated $(\mathrm{n}=8)$, followed by subtypes 3a $(n=4)$ and $1 b(n=1)$. It was not possible to differentiate between the subtypes 1a and $1 \mathrm{~b}$ in three subjects.

Anti-HCV antibody and HCV RNA levels were highest among the 48 intravenous drug users: $33.3 \%$ and $27 \%$, respectively. On other hand, anti-HCV antibody prevalence among non-intravenous drug users was only $1.5 \%(\mathrm{p}<0.0001)$.

HBV infection markers were present in $61(19.4 \%)$ individuals, of whom six $(1.9 \%)$ were HBsAg-positive. Half of those 20 anti-HCV antibody-positive individuals also showed signs of previous HBV infection. Anti-HIV antibody positivity was $1.3 \%(\mathrm{n}=4)$, all confirmed using western blot assays. Three of these individuals were already familiar with the condition.
After multiple analyses, the following variables remained associated with HCV infection: use of injected drugs, age and time served in prison (Table II).

To verify the consistency of the results of these multiple analyses, the logistical regression model was repeated, taking HCV RNA positivity as the dependent variable. Our results confirmed the independent association of HCV infection with the use of injected drugs, increasing age and time served in prison (data not shown).

A logistic model including only the 48 intravenous drug users was constructed in an attempt to find markers of increased risk of $\mathrm{HCV}$ infection. However, no association between HCV and risk variables was found. We also performed a regression analysis utilising data obtained from the 266 non-intravenous drug users; however, no association with any HCV risk factors was found (data not shown).

\section{DISCUSSION}

$\mathrm{HCV}$ infection is highly prevalent in illicit drug user populations, especially among those who use intravenous drugs. Data on this subject from Central Brazil are scarce, thus justifying further studies to explore the prevalence and predictors of HCV infection in this highrisk population.

The population studied herein consisted of mainly young people, with a low level of education. Such characteristics correspond to those found in other reports (Cobos Calleja et al. 2003). The data and analysis shown here were restricted to males, which make up the majority of the drug-using population in many report (Hahn et al. 2001, Cobos Calleja et al. 2003).

The HCV infection prevalence of $6.4 \%$ among drug users might be considered low when compared with reports from other authors (Stark et al. 1995, Rodríguez et al. 1998, Matheï et al. 2002); however, this appears to be related to the fact that only $15.3 \%$ of the study participants were intravenous drug users. When this group was considered separately, HCV infection prevalence increased to $33 \%$, which agrees with other reports that describe ranges from 37-98\% (Stark et al. 1995, Garfein et al. 1996, Rodríguez et al. 1998, Matheï et al. 2002). Two multicentre studies (AJUDE-Brazil I and II) that assessed chronic blood-borne infections in intravenous drug users in cities from the Brazilian Southeast, Northeast and Southern Regions reported anti-HCV antibody prevalence ranging from 52-61\% (Caiaffa et al. 2006, Zocratto et al. 2006). The lower HCV prevalence found in the present study could be explained by differences among the intravenous drug users' behaviour from each region or city. Another possibility is that the Caiaffa et al. (2006) and Zocratto et al. (2006) reports showed results from cross-sectional studies conducted until 2001. Since the present survey was performed in 2007, a decline in needle sharing and injection frequency as well as increased educational measures may have contributed to a decreased risk exposure. Oliveira et al. (2009b) described a remarkable decline in $\mathrm{HCV}$ infection among intravenous drug users in Rio de Janeiro (Southeast Region) over the years. 
Some authors state that the use of non-intravenouslyinjected drugs also contributes to the transmission of $\mathrm{HCV}$ due to the exposure of nasal mucosa that comes from using shared equipment (Murphy et al. 2000). In a systematic revision carried out by Scheinmann et al. (2007), the prevalence of HCV in non-intravenous drug users varied between $2.3-35.3 \%$. Among the 266 nonintravenous drug users participating in their study, only $1.5 \%$ were anti-HCV antibody-positive. This prevalence does not differ either from the general population or from that of local blood donors (Souto et al. 2003). Thus, the use of non-intravenous drugs in this sample was not characterised as a risk factor for HCV infection.

Past imprisonment was independently associated with HCV infection in our study. These results are in accordance with those of other reports showing higher HCV prevalence among prisoners and ex-convicts (Hwang et al. 2000, Caiaffa et al. 2006, Oliveira et al. 2009a). Notably, two-thirds of the study participants had a record of imprisonment, thus highlighting the pitfalls of this activity and its consequences. Despite these findings, other modes of exposure to $\mathrm{HCV}$, such as surgical procedures and unsafe sex, did not correlate with $\mathrm{HCV}$ infection in this population. Increasing age was also independently associated with $\mathrm{HCV}$ infection. As with other chronic infectious diseases, this effect may be due to a greater period of exposure.

It will be interesting to know what factors contributed to infection in the intravenous drug users' group. However, the analysis did not reveal an association between HCV and injection time or the sharing of syringes and needles. Likely, the limited intravenous drug user sample size in this study may have rendered such an association as statistically insignificant. Other Brazilian studies have shown that a longer duration of intravenous drug use is associated with a higher $\mathrm{HCV}$ infection rate (Caiaffa et al. 2006, Oliveira et al. 2009a).

In Brazil, genotype I is the most prevalent (64\%) HCV genotype identified in intravenous drug users, followed by genotype 3 (33\%) (Campiotto et al. 2005). The same proportions occur in MT (Martins et al. 2006). Genotypes $3 \mathrm{a}$ and 1a are the most prevalent among intravenous drug users worldwide (Morice et al. 2006). In Brazil, Codes et al. (2003) and Oliveira et al. (2009a) identified genotype $3 \mathrm{a}$ as the most prevalent among intravenous drug users. In the present study, the most common HCV genotypes found among users of illicit drugs were similar to the standard genotypes already reported for the region's blood donors (Souto et al. 2003).

Finally, it is notable that the prevalence of HCV infection is high among users of illicit drugs when compared with the general population in the studied region. However, this association was relegated to those that engaged in injecting illicit drug use, which represents the main risk factor for $\mathrm{HCV}$ infection worldwide. Among non-intravenous drug users, the prevalence of $\mathrm{HCV}$ was comparable to that found in the general population of the region. This finding conflicts with the belief that even non-intravenous drug users have a higher risk of acquiring $\mathrm{HCV}$ than the general population. The genotype pro- files for HCV found in this study sample were the same as those described for the general population of Central Brazil and differed from other reports regarding Brazilian intravenous drug users.

\section{REFERENCES}

Caiaffa WT, Bastos FI, Freitas LL, Mingoti SA, Proietti FA, Carneiro-Proietti AB, Gandolfi D, Doneda D, Projeto AJUDEBrasil I, Projeto AJUDE-Brasil II 2006. The contribution of two Brazilian multi-center studies to the assessment of HIV and HCV infection and prevention strategies among injecting drug users: the AJUDE-Brasil I and II Projects. Cad Saude Publica 22: 771-782.

Campiotto S, Pinho JR, Carrilho FJ, da Silva LC, Souto FJ, Spinelli V, Pereira LM, Coelho HS, Silva AO, Fonseca JC, Rosa H, Lacet CM, Bernardini AP 2005. Geographic distribution of hepatitis C virus genotypes in Brazil. Braz J Med Biol Res 38: 41-49.

Cobos Calleja T, Casanueva Gutierrez M, Gonzales J 2003. Perfil de los usuarios de drogas ingresados en un hospital. An Med Interna 20: 8-17.

Codes L, de Freitas LA, Santos-Jesus R, Vivitsky L, Silva LK, Trepo C, Reis MG, Paraná R 2003. Comparative study of hepatitis C virus genotypes 1 and 3 in Salvador, Bahia, Brazil. Bra J Infect Dis 7: 409-417.

Garfein RS, Vlahov D, Galai N, Doherty MC, Nelson KE 1996. Viral infections in short-term injection drug users: the prevalence of the hepatitis $\mathrm{C}$, hepatitis $\mathrm{B}$, human immunodeficiency and human T-lymphotropic viruses. Am J Public Health 86: 655-661.

Ginabreda MGP, Yoshida CFT, Niel C 1997. Genomic characterization of Brazilian hepatitis $\mathrm{C}$ virus genotypes 1a and 1b. Braz $J$ Med Biol Res 30: 339-345.

Hahn JA, Page-Shafer K, Lum PJ, Ochoa K, Moss AR 2001. Hepatitis $\mathrm{C}$ virus infection and needle exchange use among young injection drug users in San Francisco. Hepatology 34: 180-187.

Hwang LY, Ross MW, Zack C, Bull L, Rickman K, Holleman M 2000. Prevalence of sexually transmitted infections and associated risk factors among populations of drug abusers. Clin Infect Dis 31: 920-926.

Kew M, François G, Lavanchy D, Margolis H, Van Damme P, Grob P, Hallauer J, Shouval D, Leroux-Roels G, Meheus A 2004. Prevention of hepatitis C virus infection. J Viral Hepat 11: 198-205.

Lanternier F, Roulot D, Bentata M, Pol S, Viard JP, Gordien E, Jeantils V, Ziol M, Lortholary O 2007. Risks factors of liver fibrosis in a cohort of intravenous drug users coinfected with HIV and HCV in the HAART era: the role of mixed steatosis. Gastroenterol Clin Biol 31: 822-827.

Martins RMB, Teles SA, Freitas NR, Motta-Castro ARC, Souto FJD, Mussi AH 2006. Distribution of hepatitis C virus genotypes among blood donors from Mid-West region of Brazil. Rev Inst Med Trop Sao Paulo 48: 1-3.

Matheï C, Buntinx F, Van Damme P 2002. Seroprevalence of hepatitis $\mathrm{C}$ markers among intravenous drug users in western European contries: a systematic review. J Viral Hepat 9: 157-173.

Memon MI, Memon MA 2002. Hepatitis C: an epidemiological review. J Viral Hepat 9: 84-100.

Morice Y, Cantaloube JF, Beaucourt S, Barbotte L, De Gendt S, Gonçales FL Butterworth L, Cooksley G, Gish RG, Beaugrand M, Fay F, Fay O, Gonzalez JE, Martins RM, Dhumeaux D, Vanderborght B, Stuyver L, Sablon E, de Lamballerie X, Pawlotsky JM 2006 Molecular epidemiology of hepatitis C virus subtype 3a in injecting drug users. J Med Virol 78: 1296-1303. 
Murphy EL, Bryzman SM, Glynn SA, Ameti DI, Thomson RA, Williams AE, Nass CC, Ownby HE, Schreiber GB, Kong F, Neal $\mathrm{KR}$, Nemo GJ 2000. Risk factors for hepatitis C virus infection in United States blood donors. Hepatology 31: 756-762.

Oliveira M de L, Bastos FI, Telles PR, Hacker M de A, Oliveira SA, Miguel JC, Yoshida CF 2009a. Epidemiological and genetic analyses of hepatitis $\mathrm{C}$ virus transmission among young/short and long-term injecting drug users from Rio de Janeiro, Brazil. J Clin Virol 44: 200-206.

Oliveira ML, Yoshida CF, Telles PR, Hacker MA, Oliveira SA, Miguel JC, do O KM, Bastos FI 2009b. Trends in HCV prevalence, risk factors and distribution of viral genotypes in injecting drug users: findings from two cross-sectional studies. Epidemiol Infect 137: 970-979.

Paraná R, Vitvitsky L, Berby F, Portugal M, Cotrim HP, Cavalcante A, Lyra L, Trepó C 2000. HCV infection in Northeastern Brazil: unexpected high prevalence of genotype $3 \mathrm{a}$ and absence of African genotypes. Arq Gastroenterol 37: 213-216.

Rodríguez OES, Gil MLM, Santana JFH, Cañal JML, Sánchez AMM 1998. Prevalence of serologic markers of HBV, HDV, HCV and
HIV in non-injection drug users compared to injection drug users in Gran Canaria, Spain. Eur J Epidemiol 14: 555-561.

Sablon E, Shapiro F 2004. Hepatitis B and C genotyping: methodologies and implications for patient management. $J$ Gastroenterol Hepatol 19: S329-S337.

Scheinmann R, Hagana H, Lelutiu-Weinberg C, Stern R, Des Jarlais DC, Floma PL, Strauss S 2007. Non-injection drug use and hepatitis C virus: a systematic review. Drug Alcohol Depend 89: 1-12.

Shepard CW, Finelli L, Alter MJ 2005. Global epidemiology of hepatitis C virus infection. Lancet Infect Dis 5: 558-567.

Souto FJ, da Silva AG, Yonamine F 2003. Risk of hepatitis among Brazilian ex-soccer players. Mem Inst Oswaldo Cruz 98: 1025-1026.

Stark K, Schreier E, Müller R, Wirth D, Driesel G, Bienzle U 1995. Prevalence and determinants of anti-HCV seropositivity and of $\mathrm{HCV}$ genotype among intravenous drug users in Berlin. Scand $J$ Infect Dis 27: 331-337.

Zocratto KB, Caiaffa WT, Proietti FA, Carneiro-Proietti AB, Mingoti SA, Ribeiro GJ, Projeto AJUDE-Brasil I 2006. HCV and HIV infection and co-infection: injecting drug use and sexual behavior, AJUDE-Brasil I Project. Cad Saude Publica 22: 839-848. 